\title{
Spatial Planning and Architectural Innovation in the Roman Town of Ocriculum
}

\section{Giacomo Antonelli}

"Sapienza" University of Rome, Faculty of Arts and Humanities, Department of Classics, Piazzale Aldo Moro 5, 00185 Rome, Italy

Corresponding author: giacomo.antonelli@uniroma1.it

Гrossef http://dx.doi.org/10.5755/j01.sace.22.1.21086,

The Roman settlement of Ocriculum (Otricoli, TR - Umbria), built on a tufa slope between the Tiber valley to the north and the San Vittore valley to the south, was established on massive substructures, which allowed the exploitation of a larger area. Albeit being relatively neglected by modern scholarship, these structures are none the less crucial to a thorough analysis of the urban planning of Ocriculum.

Two buildings are mutually connected inside the city, even if they were not built at the same time: the bath complex, built in the mid-2nd century $A D$ and restored until the 4th-5th cent. AD, and the underlying culvert, in which the San Vittore still flows, which was certainly built before the baths and most likely alongside the substructures. This artificial terrace, on which the baths lie and under which the channel runs, has been the first human alteration of the slope. The bath complex, although not entirely preserved, features several interesting architectural innovations.

Modern technologies were employed alongside traditional methodologies to analyse the two buildings. This allowed not only a 3D reconstruction of these structures, but also a deep knowledge of the urban development and architectural history of Ocriculum.

The culvert is part of the earliest attempts to shape the natural landscape for settlement purposes. On the overlying terrace there should have lain not only the bath complex, but also the theatre scene and its porticus post scaenam (both no longer visible). For this reason, the theatre is later than the culvert and not earlier (Hay-Keay-Millet, 2013). Consequently, the close "Great Substructures" belong to the same construction phase of the theatre, because they support the thrust of the upper terrace, on which was most likely found the political and religious centre of Ocriculum.

Furthermore, the octagonal hall of the baths and the smaller circular hall (the only preserved rooms of the entire complex) are an important proof of the wealth of this city. They were roofed by a so-called shellshaped dome (consisting of 41 nails) and by a dodecagonal cross-vault, consisting of six larger convex wedges alternating with six smaller ones: it seems to be a hexagonal segmental dome. The first one, built as a pluri-composed cross-vault, surely functioned as a hemispherical dome. It lies on a circular springing, that is connected with the underlying octagonal hall through triangular ashlars, covered with plaster. Both the "shell-shaped" dome and the angular connectors are an innovation and also an unicum in Roman architecture. This allows to identify Ocriculum as a very rich town, inhabited by wealthy people enriched thanks to the trades on the Tiber and the Via Flaminia, but also by famous people like Milone (Cic., Pro Milone, 24, 64) and Pompea Celerina, the rich mother-in-law of Pliny the young (Plin., Ep., I, 4, 1). Furthermore, Ocriculum was seamlessly inhabited even after the collapse of the Roman Empire. The baths have repeatedly been refurbished up to the 4th-5th century: this testifies to the importance of this building for the urban community. In the end, the absence of fortifications could be explained with the identification of this settlement near the port as a monumental detachment of the city on the top of the hill (which was never abandoned).

Keywords: architectural innovation, culvert, Ocriculum, Thermae, urban planning.

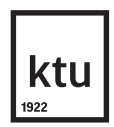

Journal of Sustainable Architecture and Civil Engineering Vol. 1 / No. 22 / 2018 pp. 11-26 DOI 10.5755/j01.sace.22.1.21086 (c) Kaunas University of Technology 
The ancient town of Ocriculum was established on the left bank of the Tiber; the foundation cannot satisfactorily be dated. The name (Greek 'okpıs', Etruscan 'ukar', Umbrian 'ocar') means 'mountain'; with the Latin suffix '-ulum' the toponym is that of a little mountain, a hill. Alongside the name, a considerable number of Orientalizing-period tombs all around the hill it suggests that the main settlement lay on the top of the hill, where is now found the modern city of Otricoli. The position was clearly determined by the purpose of controlling of the river, which allowed trades among Etruscans, Umbrians, Sabins, Faliscans and Latins and had a crucial role for the development of Ocriculum. Now as it was then, Otricoli is part of the province of Terni (according to Cenciaioli (2001, 302), Ocriculum was the port on the Tiber for the Umbrian people who lived in the Nahar Valley, where Interamna Nahars, modern-day Terni, was founded) and borders with the province of Viterbo (Etruria) to the west, with the province of Rieti (Sabina) to the south-east and with the municipality of Civita Castellana (ancient Falerii) to the south-west. Furthermore, Ocriculum is directly connected with Rome by modern-day motorway A1 e the SS3 (national road) Flaminia, which follows approximately the path of the ancient Via Flaminia, which crosses Otricoli since 220 BC.

The grave goods from Orientalizing-period tombs allow to date the earliest frequentation of the site to the 7th century BC. In the 1980s, archaeological remains were found in the area called "La Scorga", on the north of San Vittore's church. This evidence, dated to the 8th century BC (Filippi-Pacciarelli, 1991, 68-70), allowed to backdate the earliest frequentation of both the land and the landing (but it is possible that there was a more ancient one). "La Scorga" is a tuff terrace that insists on the west of the ancient port and allows to control the whole Tiber valley. This is a further demonstration that the port was the most important reason for the foundation of Ocriculum.

In the 4th-3rd century BC, the wealth of the city increased so much as to allow the (re)construction of the city walls on the hill settlement and the establishment of a religious building in the area called "Cisterna", near the port. This development was possible even thanks to the agreement with the rising Roman force in $308 \mathrm{BC}$ (Liv. IX, 42, 20) and to the forthcoming building of the Via Flaminia. During the late-Republican/early-imperial period (CIL VI, 872=31188 on the Lex Rufrena of $42 \mathrm{BC}$ and found in the Forum of Ocriculum) the settlement near the port experienced a large urbanization: the deep valley in which the San Vittore stream flows was regulated with massive substructures (Fig. 1), starting from the culvert. The most important buildings of any roman town (e.g. forum, basilica, temples (?) etc.), were erected on the main terrace; several water reservoirs were built in the highest areas of the site. This monumental centre seems not to have ever had defensive walls, perhaps due to its construction period. As Augustus rose to power, Italy was entirely pacified and several towns, (re)founded in that period, had no fortifications whatsoever.

In the 2 nd century AD another important building was edified: the bath complex is the only structure provided with several inscriptions (another inscription might refer to the theatre scene, see below). Inscriptions give information on the founder of the baths and report the names of the people who refurbished the building in AD 341 and in the late-4th/early-5th century AD. This demonstrates that the building was very important to the citizens, even in the early Christian period. There is also another piece of evidence for the frequentation of the settlement after the collapse of the Empire: an early Christian inscription mentioning a possible baptistery built near the forum in the 7th century AD $(I C I \mathrm{VI}, 3)$. From this moment onwards, the lower town started to be abandoned in favour of the upper one. Although ancient authors included Ocriculum in the list of cities destroyed after the Social War at the beginning of the 1st century BC (Flor., Epit., II, 6, 11.), it is rather impossible that the upper settlement has been uninhabited for centuries, while the lower developed and enriched even without fortifications, especially during the Barbarian Invasion of the 4th-6th centuries (Pietrangeli, 1978, 11). A Roman reservoir brought to light in the city hall square in the modern town testifies to the frequentation of the upper city as early as the republican/imperial period (Cenciaioli, 2008, 812). 


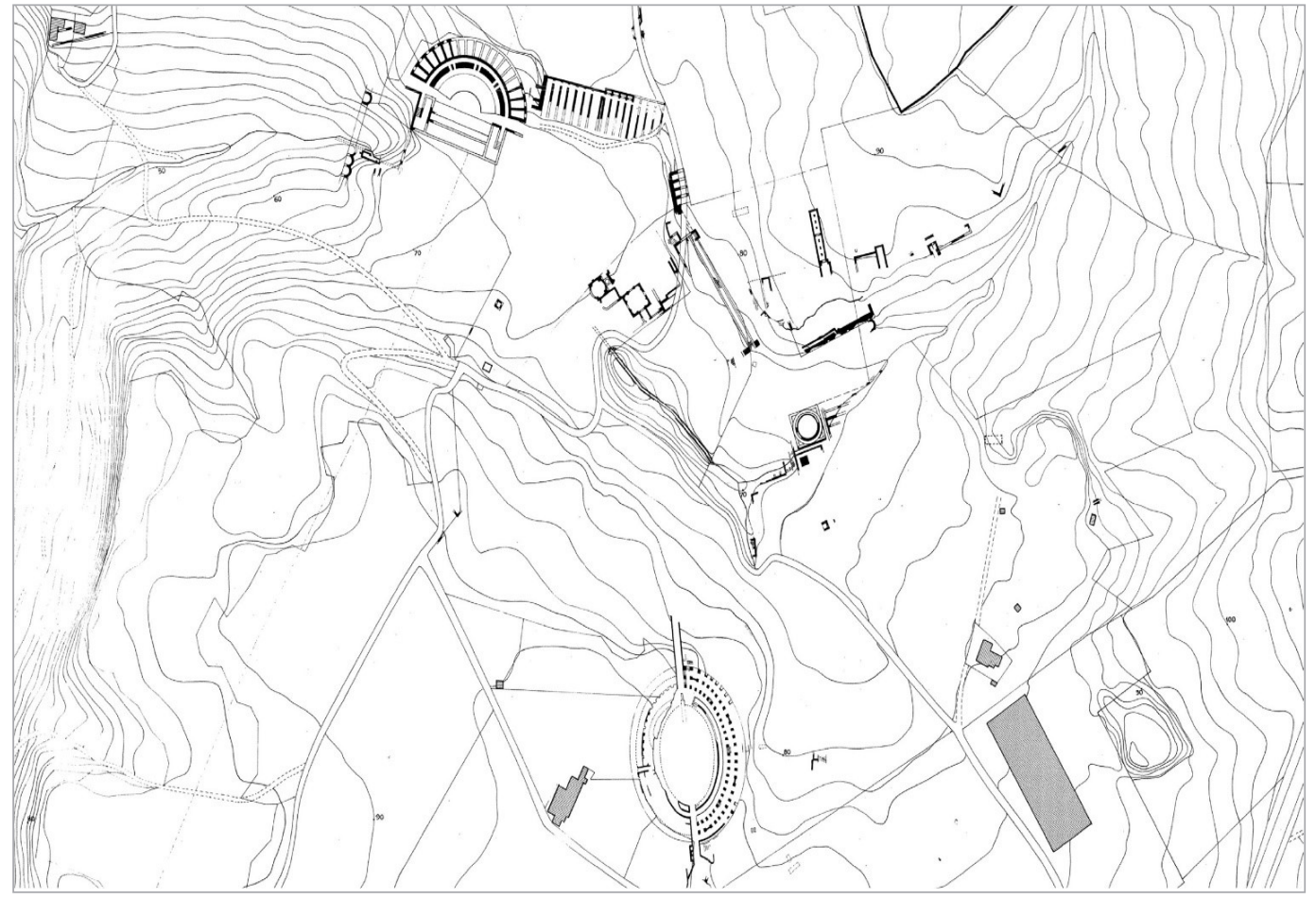

Fig. 1

Main area of the Archaeological Park of Ocriculum (De Rubertis, 2011, fig. 2)

After its abandonment, the lower settlement became a building material quarry for the construction of the upper medieval city. A considerable number of architectural and sculptural fragments, as well as inscriptions coming from Ocriculum feature in modern Otricoli, re-used as gates, windows, bollards and as decoration for private, public and religious buildings. Cubilia were recycled in the Collegiata for its first building phase in opus mixtum, dating back to the 9th century. Sucessively, this area was covered by a thick layer of alluvial soil (about $5 / 6$ meters in the highest parts), transported by the San Vittore stream. The extension of this muddy soil follows the course of the stream, even in the underground passage. The alluvial soil converted a monumental centre into grazing and farming lands.

In the latter half of the 18th century, excavations encouraged by the Pope, directed by G. Pannini and published by G. A. Guattani, brought new interest in the studies on Ocriculum. The first urban plan of the ancient city was drawn, and several artistic objects and architectural elements were studied and restored and thenceforth exposed in Vatican Museums: the bust of Juppiter (so-called Ocriculanum), the sculptural group from the Basilica, architectural fragments from theatre and the beautiful mosaic from the octagonal hall of the bath complex.

Afterwards, no relevant research on Ocriculum was undertaken, until C. Pietrangeli's works: since the 1940s, he led a thorough and comprehensive research on the city. He investigated every aspect of the settlement, and addressed its history from prehistory to modern times. After Pietrangeli's research the Archaeological Superintendence of Umbria took over the conservation of the area and since $2000 \mathrm{Dr}$ Luana Cenciaioli led research on the city, publishing several works. Further research was undertaken by the British School at Rome, which led geophysical and geomagnetical surveys and offered a provisional reconstruction of the urban plan.

The landscape was considerably shaped by human actions and natural weathering. The San Vittore stream has always been the main geomorphological agent inside the settlement, and the Tiber did the same outside. Even if it was no longer navigable as early 1834, the Tiber definitively changed its course in 1846 after three violent floods which cut out the meander where the ancient harbour was. 
Now it flows too close the San Vittore church and abbey. The latter has partially been destroyed by the river (Rossi-Caponeri, 2012, 28 and 36). Romans felt the necessity of regularising the San Vittore valley with at least three large terraces, which allowed the constructions of the main buildings of the city: the Theatre, the Basilica, the forum, a temple (?) and, in the 2nd century, the bath complex. These terraces are still supported by substructures consisting of (from top to bottom): a long wall; a sequence of small underground halls (so-called reservoirs) and shorter walls, a nymphaeum and other structures behind it, two vaulted substructures and, not far from them, the theatre; at the end, an invisible underground channel, where the San Vittore stream flows.

Recent archaeological studies consider this culvert and the terrace above it immediately previous the baths and later than the Theatre. This because they think that both the culvert and the terrace are strictly linked with the construction of the baths, maintaining that the first upper part of the conduit was made with bricks and so identifying it as baths' aqueduct (Hey-Keay-Millet, 2013, 59-60). Furthermore, Bertacchini holds to be true the hypothesis based on which the terrace was created before the channel. She has reconstructed the formation of this complex, recognizing the substructures downstream of the Theatre as a dam that, blocking the stream flowing, should have created an artificial basin. When it had let deposit enough sediments, Romans would have built another dam near the thermae and from here would have dug an underground channel (Bertacchini-Cenciaioli, 2003, 215; Bertacchini, 2006, 17).

This hypothesis is unrealistic and it also starts from not completely correct analysis and interpretation of geological and archaeological data, forcing the real situation. How can a culvert used as a sewer (see below) supply a bath complex? How can modern literature say that this conduit was made with bricks, if its only part built like this is the final (and later) one? Are we sure that roman engineers would prefer to flood a valley (very close to the already existing city, as British scholars say (Hey-Keay-Millet, 2013, 143-151)), wait for its natural and long-lasting filling and then dig a channel into still not coherent sediments, rather than do it another way? All relative data suggest that it would be more linear and simple to build immediately the conduit and, at the same time, keep filling the valley up to finally cover it.

Furthermore the bath complex has never been studied in depth from an architectural point of view, but its importance in this field is really huge compared to an apparently normal Roman municipium on the Tiber's banks. Also its relationship with the culvert is not based on the almost contemporaneity of construction, but on urban and hydraulic needs.

With the follow considerations, I will try to cast new light on these buildings, considering at the same time geomorphological, archaeological, architectural and urban features. With an autoptic analysis and structural survey of buildings, identifying the real geological stratigraphy and considering quotas of each monument, I will try to explain how the channel was the first and most important land regularization of roman time, which was its use, also relative to the Thermae, and why both buildings are still so significant, from both artistic, architectural and urban point of view. They finally will show clearly how much important was the city of Ocriculum and why it cannot be ignored any longer.

As every topographic research, the field work has been essential: site inspection and autoptic vision are the most important, fundamental, primary key for knowledge of ancient monument. Where it was possible, we visited both baths and culvert and surveyed structures directly, in a manual way, and indirectly, through total station and photogrammetry by structure-from-motion programs. Since culvert is today partly obstructed, so that is indispensable going there only with a professional speleological group, data collected here are incomplete, although enough to support our hypothesis.

Furthermore, many information can be taken by previous researches about Otricoli, that refer also to monuments that are no longer visible today. Considering that the information taken by these 
studies could no longer be verified, unless supported by photos or drawings, they must be considered with prudence. Anyway they can be very interesting and useful to understand the remains still visible. Very important, from this point of view, are historical archive sources that makepossible to have an open window on past centuries.

Moreover the overlapping of different kinds of maps made possible to bring back a more credible context about these two connected monuments. Geological and geomorphological maps, altimetric map with $\mathrm{m} 1$ equidistance, old archaeological maps and personal survey map together furnished a lot of information. GIS software have been very useful: they permit to overlap many raster and vector objects, in order to make different kind of analyses and considerations.

It is quite important to underline that all these items must be interpolate among each other to allow any realistic reconstruction of the monuments' history. Only with a complete overview of every inherent element we can suggest a reasonable historical reconstruction.

Most of the underground channel is well-preserved, although it is filled by sediments up to a considerable level. Even if they allow the water-flowing, sediments prevent the channel from being easily inspected: it can be visited for few meters only.

From the end toward upstream, it is possible to traverse about just $10 \mathrm{~m}$ into a rectangular section tight tunnel (about $\mathrm{m} \mathrm{1.30/1.00} \mathrm{high} \mathrm{and} \mathrm{m} 0.90$ large), made in bricks (Fig. 2). Covered that distance, there is a tangle of logs that hinders passage. None the less, it is still possible to see beyond the sediments. After less than one meter, the section changes and it seems to be vaulted and wider. At the end of this part, towards the Tiber, there lie a few ruined buildings. They are built in bricks and other materials that seem to have been recycled (travertine fragments at the angles of the walls, leucite on the channel's floor). Furthermore, walls are covered by plaster on the supposedly-exterior side (which should have be against the soil) (Fig. 3).

Near these brick structures, on each side, there lie remains of great niches aligned with each other and built in tuff opus reticulatum, like most monuments of Ocriculum. In addition, above the last part

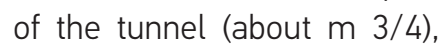
there lie two wall sherds, built in opus reticulatum and aligned with each other, with the aforementioned niches and with the west side of the theatre's scene.

Another accessible section of the channel is more upstream, near the bath complex and more than $\mathrm{m} 10$ under modern-day ground level, into a deep gorge. Here it is easier to enter the conduit, as it is $\mathrm{m}$ 1.65 large and more than $\mathrm{m}$ 2 high; walls are built in opus
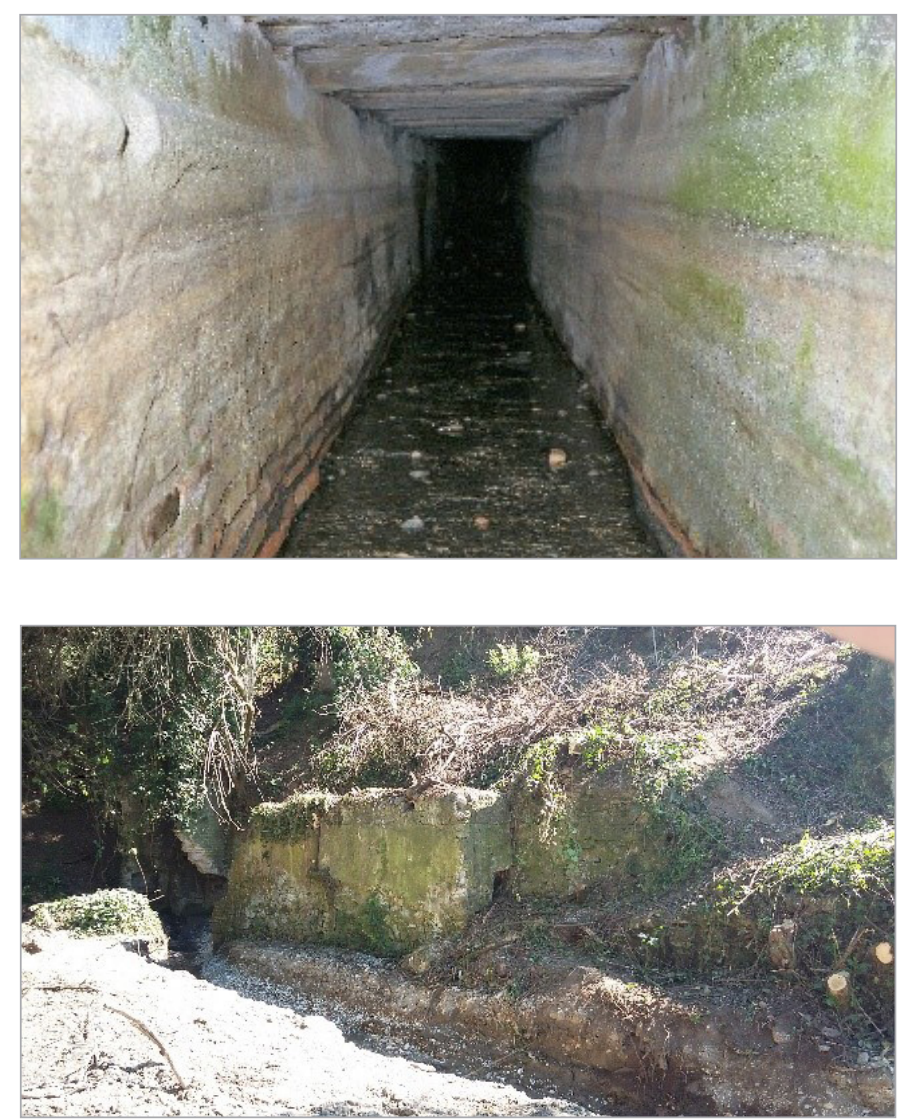

\section{Results}

Fig. 2

Last brick-made rectangular section of the culvert (photograph by the author)
Fig. 3

Structures brick-made at the end of the culvert (photograph by the author) 


\section{Fig. 4}

Entrance near the baths (photograph by the author)

\section{Fig. 5}

Archive photo from Ciotti fund (MAEC, Binder

"Carsulae D", folder B)
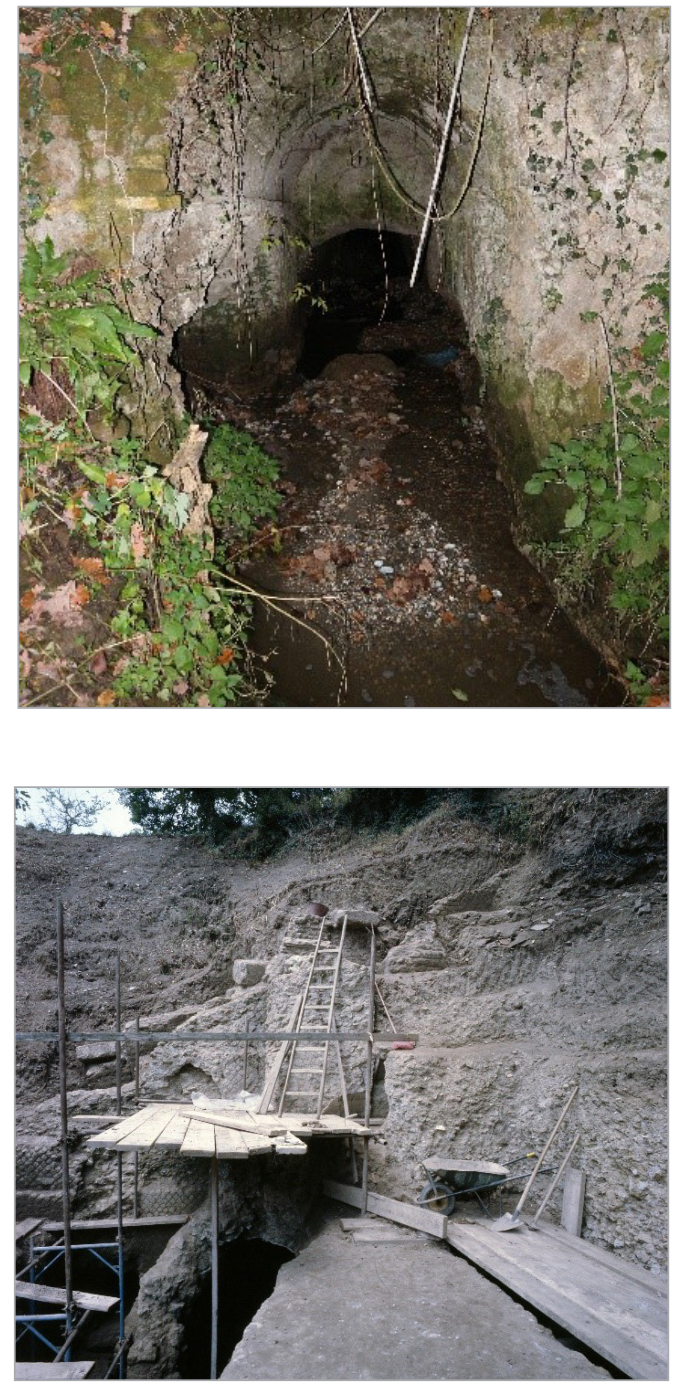

reticulatum and the barrel-vault (springing at about $\mathrm{m} \mathrm{1,60)}$ features on the concrete the traces of wooden formwork. Surfaces are covered by calcareous concretions. Going downstream, there is immediately a partition concrete wall suspended over the passage (Fig. 4). After it, there is a restored portion in modern tight brick (perhaps hollow bricks) dated to the 1960s.

This modern work is visible also outside, in a concrete underground hall, where it is possible to see a wealth of archaeological evidence. First, a small, brick-made conduit comes from the bath complex and is found at a higher level than that of the main culvert. Furthermore, a massive wall in opus reticulatum (as big as the modern location, about $\mathrm{m} 6$ high and $\mathrm{m} 9$ long, although it most likely might have been higher), orthogonal to the channel and tapered upwards through small folds. Finally, it is possible to observe a pillar abutting the wall and made of tuff ashlars, $\mathrm{m} 0.90$ long and $\mathrm{m}$ 0.60 wide. It does not seem to be part of the aforementioned wall, but rather to feature the springing of an arch.

Thanks to archive photos (Fig. 5) and to De Rubertis (Fig. 6), who undertook structural surveys of excavations, it is possible to reconstruct the original state of the buildings before the restorations. The southern wall of the main conduit collapsed for a section of about $\mathrm{m} \mathrm{4}$;
Fig. 6

Architectural survey of evidence in the previous photo (De Rubertis, 2011, fig. 45)

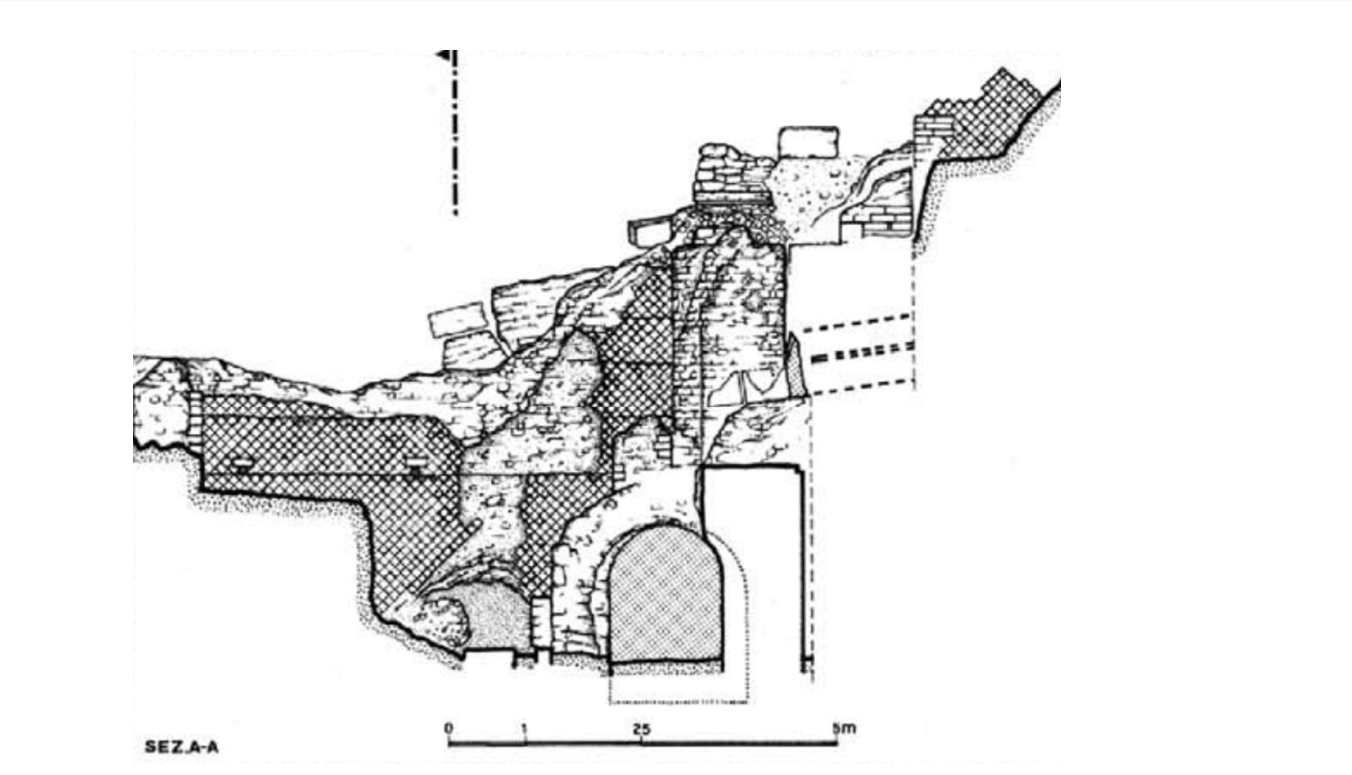


the vault collapsed as well. The channel was partially backfilled; the stream could none the less flow, but sediment accumulation was more substantial thenceforth. At the time of the excavations led by U. Ciotti (Superintendence of Umbria) the structures described above were brought to light and the conduit was fixed with hollow bricks and reinforced concrete. In particular, an archive photo and the drawings produced by De Rubertis show that the wall in opus reticulatum continues over the channel, towards the bath complex, up to $m 8$ in height and to $m 4$ in length. Furthermore, the extrados of the vault looks like plane and squared upstream and curved near the wall.

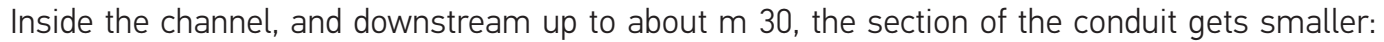
width and height decrease respectively up to $\mathrm{m} 0.90$ and less than $\mathrm{m} 1.00$. Sediments have progressively reduced the height of the channel, as they reach the vault springing and cover the walls almost completely. As far as width is concerned, however, it is clear that it varied considerably through the course of the channel. Inspections could not be led further, due to safety issues. The inspected section of the channel extends approximately to the round hall of the baths. Most likely, it is the same point reached by C. Orlandi in 1753 (ASR, Buon Governo, Serie II, folder 3269). The architect left an important description of this monument as he proposed to empty the channel in order to activate the abandoned mill at the end of it, identifying the standing bricks-made structures as an ancient water wheel (Another later document, ASR, Camerale II, Molini, folder 25, file 276; dating back to 1834 , reports the request for building a water-mill in the no-longer-navigable branch of the Tiber, since the so-called "mill of San Vittore" had not been working for a lot of time).

The modern entrance of the conduit near the thermae is not its original access. Immediately upstream there is a short sloping surface, composed of concrete mixed with various materials, connected with another more sloping surface made of concrete and tuff fragments. A little farther down, there lies a long section of channel, built in the same way as the one just downstream: walls in opus reticulatum, concrete barrel vault and same size. This part, about 40 meters long, is not used by the watercourse nowadays because, in the middle, it is completely obstructed by mud sediments, some building materials and some huge blocks of tuff (Fig. 7). The San Vittore stream flows outside this part nowadays, on the southern side, uncovering the wall surface which used to abut to the soil. Traces left by wooden formworks are visible.

In the not-completely-obstructed part of the channel, some circular holes are visible on the top of the vault (Fig. 8). They are not the results of collapses and seem to have intentionally been realised at the same time of the vault. Some of them are not clogged by the soil and allow the sunlight to pass through.

Unfortunately, this section of the channel has considerably been backfilled by sediments which almost reach the vault springing. In this point a section more upstream has springing less high than the next section downstream. It seems that this upstream portion having gone down, or conversely the downstream one having gone up, along the joint between the two parts. Actually there is no evidence of both hypothesis and surely there is a different explanation: only excavations could better clarify what occurred here.
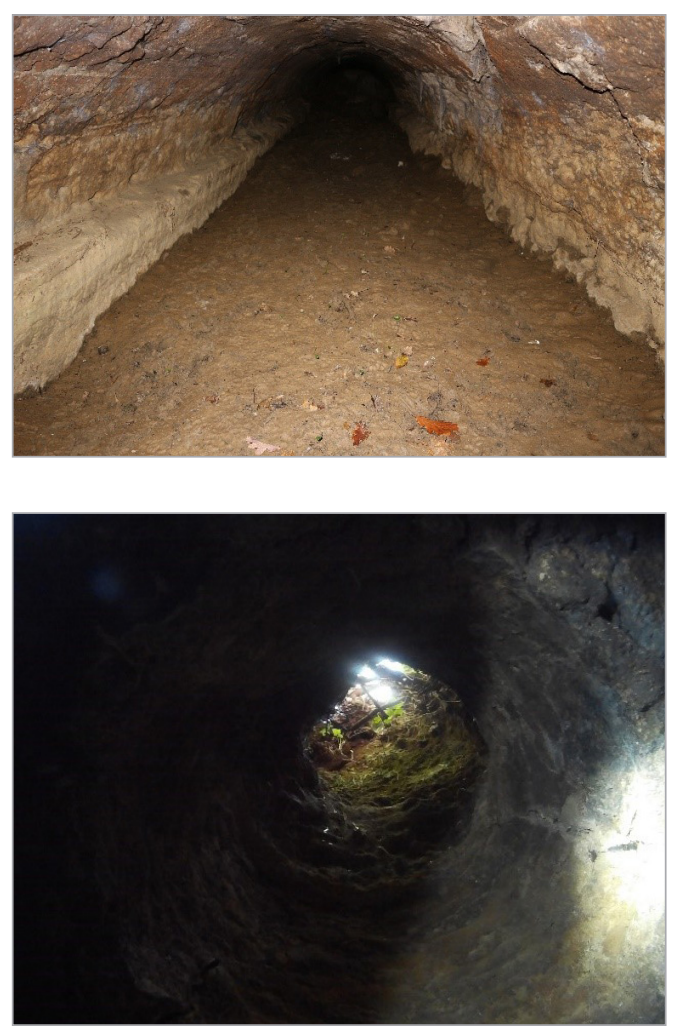

Fig. 7

First unused section of culvert: note the sediments (photograph by the author)

\section{Fig. 8}

Hole in the vault of the culvert (photograph by the author) 
Further to this occluded section, there is no evidence for the channel and little upstream the remains of the Via Flaminia are cut by the watercourse, after a marked bend to north-east. As the reported measures demonstrate, it is probable that the ancient San Vittore stream had a major flow rate than that of the modern one, so it is even more unrealistic to think that it ran over the road. Most likely, there was a little bridge, or the channel started east of the road and of the tombs along it, before running below the bath complex.

Two rooms of the bath complex are currently visible, alongside a pillar and some structures preserved only at the ground level. The building features today different ground levels, both inside and outside, mostly due to intense excavations.

At the end of the 18th century, pope Pius VI carried out extensive excavations. Several inscriptions, sculptures and fine marbles have been found in the thermae; also the polychrome mosaic, today in the Round Hall of the Vatican Museums (Pietrangeli, 1944, 47-104; Pietrangeli, 1958, 115-119), was found in the bath complex. It decorated the floor of the octagonal hall of the baths and, when it was found, it was cut in 108 pieces and brought to Rome on the Tiber. These excavations left large holes, which can now be identified inside the two surviving halls and north-east of them. Inside the rooms, moreover, the existing floor level was even more lowered by refurbishments undertaken by the Superintendence of Umbria in the 1960s. At the end, after earthquakes occurred in 1997 in Umbria, the Superintendence dug some trenches to reinforce the structures: in the octagonal hall, it was possible to reach the preparation layer of the mosaic, about $\mathrm{m} 2.5 / 3$ below the modern floor level (Cenciaioli, 2008, 817). It provides the height of the "loamy sand due to mudflow" layer (Bertacchini-Cenciaioli, 2008, 845) that covers this building and the lower part of the settlement, from the tombs to the theatre, except for the gorge: approximately between $\max \mathrm{m} 6$ and $\min \mathrm{m} 2$.

The bath complex is the only visible monument of the ancient town which yielded inscriptions inherent to it. Incsciptions give information on the founder of the baths, on the building period and on refurbishments. Lucius Iulius Iulianus (CIL XI, 4090) built thermas Ocricolanis at least from AD

Fig. 9

Plan of the bath complex with prospection's results and with Pannini's plan superimposed (HeyKeay-Millet, 2013 fig. 3.30)

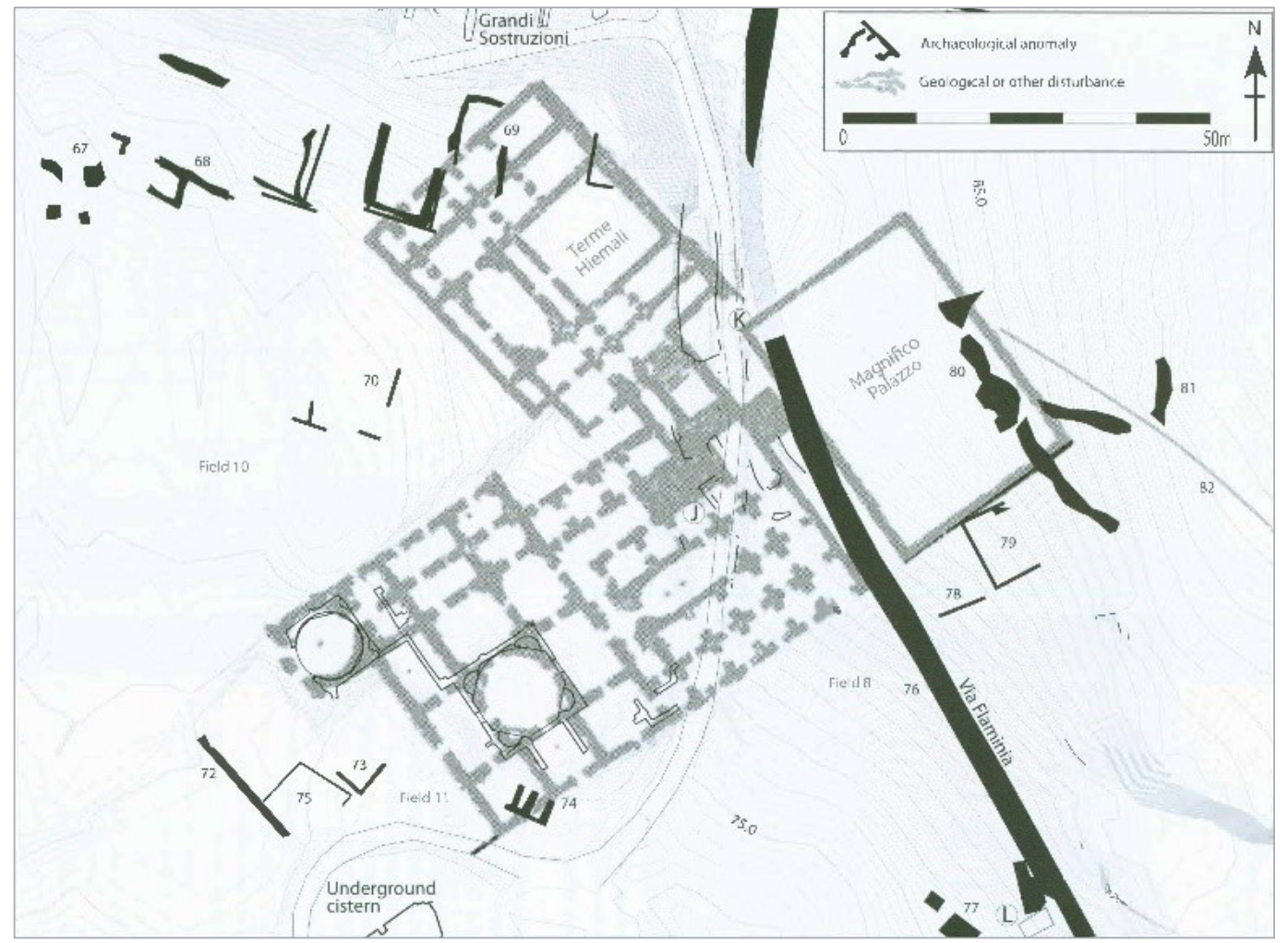


145/150 (CIL XV, 1078). Between the 4th and the 5th century AD thermas hiemales were restored first by Sextus Cluvius Martinus and Marcus Caesolius Saturninus (CIL XI, 4095-4097) and then by Caius Volusius Victor (CIL XI, 4094). These different buildings, the thermae and the thermae hiemales, were reported by the director of the papal excavations, G. Pannini, in his map of the ancient city. According to him, the thermae should be identified with the visible remains, whereas the thermae hiemales should have been further north, toward the so-called Great Substructures, where nothing is visible nowadays. Here surveys led by the British School at Rome identified buried structures, which do not feature, nevertheless, the same alignment of those drawn by Pannini. Instead, they seem topographically coherent with the near substructures (Fig. 9; Hey-Keay-Millet, 2013, 60-61). This caused some doubts both about Pannini's work and about the existence of the thermae hiemales. However, inscriptions mention the thermae hiemales, and this demonstrates their presence in the town, probably near the main bath complex, as Pannini drew in his plan. Only excavations could solve this problem.

The bath complex is built in bricks and shingles and has an articulated game of shapes, as far as it is possible to see. The octagonal hall (about $\mathrm{m} 4.90$ in side; Fig. 10) is inscribed in a square of $\mathrm{m} 11.78$ side. In the resulting space between these two forms, four semi-circular niches are obtained, featuring half-domes and underlying triangular rooms. The other four sides feature an access each, the biggest of which, on the south-eastern side, is $\mathrm{m} 4.50$ large, whereas the oth-

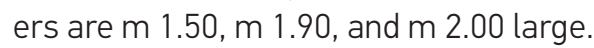
Another passage should have been inside the southern niche, where there is a segmental arch at the ground level. Behind this recess, a wall suggests the presence of another buried room, related to this passage. The principal access on the south-east is flanked by two parallel walls on which there should have been two little recesses. They are m 5.10 long and at the end they should have featured an orthogonal partition wall (with access of $m 3.40$ large), which created a squared vestibule before the octagonal hall (Fig. 11).

The best-preserved section of this room is on the north-western side (Fig. 12). Here, the only portion of the dome still stands on. Springing at about $\mathrm{m} 8$ and conserved for over m 3 , just little over haunch, it must have been bigger than $\mathrm{m} 12$. This kind of dome is the only one found in the whole Roman world. The so-called "shell-shaped" dome features a series of little concrete nails starting from brick lunettes long $\mathrm{m}$ 0.90: only 10 are preserved nowadays, but then they must have been 41 , considering that the
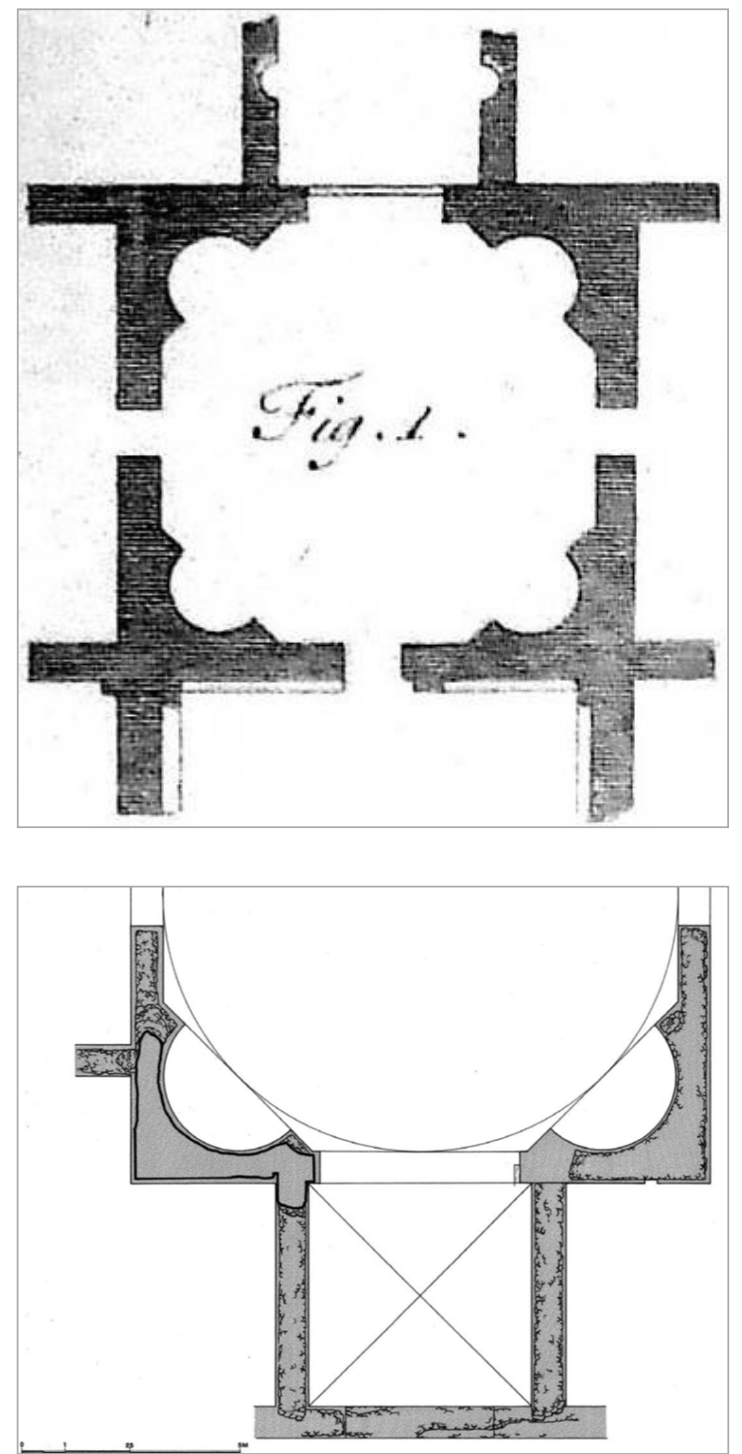

Fig. 10

Octagonal hall plan (Uggeri, 1802, tav. XXXII)

Fig. 11

Particular of a modern plan of the octagonal hall (De Rubertis, 2011, fig. 37) 
Fig. 12

Architectural survey of the north-western section of the octagonal hall (drawing by the author)

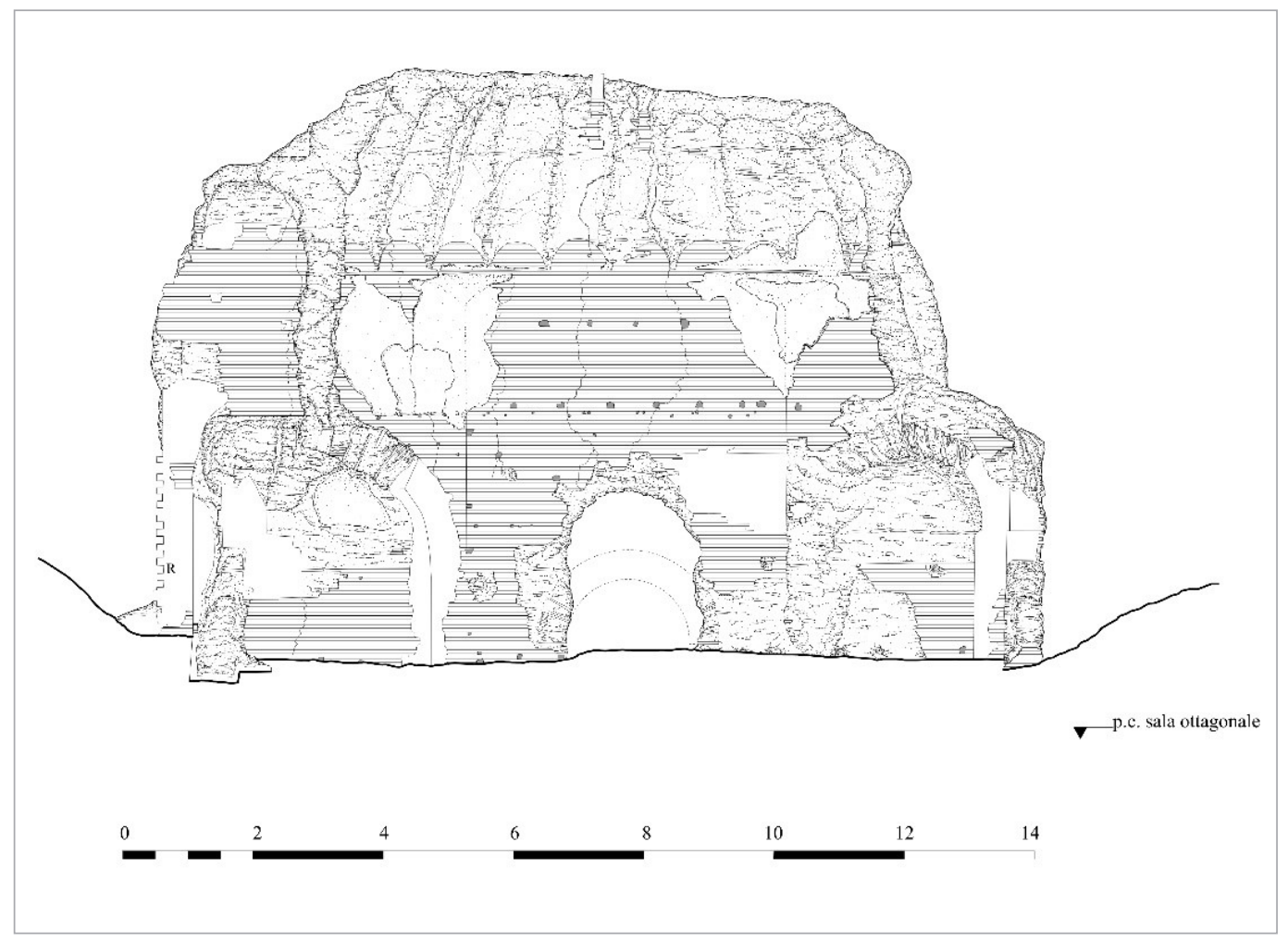

circumference of the dome at the springing is about $\mathrm{m}$ 36.9. Although it looks like a segmental dome, it should have worked effectively as a semi-spherical dome, because the weight was divided in order to distribute on the whole springing surface. Furthermore, corresponding to haunch there is a brick line from which starts a brick-made rib, in correspondence to the centre of the north-western wall.

In order to connect the octagonal plan of the room with the circular one of the roofing, Roman engineers used triangular connection. Near the top of the walls, angular bricks jut progressively and gradually hide the corners. The surface is then covered with plaster. Plaster, in fact, was on the highest part of the walls, whereas the lower featured a marble veneer (Cenciaioli, 2012, 173).

In the other circular room, likewise, the dome is preserved just over the haunch, but almost in the whole circumference (Fig. 13). It is possible to see traces of the tubuli used as flues and connected with the hypocaustum below the floor. This allows us to identify this as a heated room, most likely as the hottest one, because of its small size ( $\mathrm{m} 9$ diameter) and because of a big window on southwest side, which lets sunlight in in the warmest hours of the day. The accesses to the room should have been on the south-eastern and north-eastern sides, the former from another warmed room and the latter one from an unknown part of the thermae. Regarding the dome, two kinds of lunettes are preserved, six large as those of the octagonal hall ( $\mathrm{m} 0.90$ in length) and six much larger (between $\mathrm{m} 3.50$ and $\mathrm{m} 4.85$ in length). So, it is possible to identify here a real segmental dome, articulated on a very unusual shape (irregular dodecagon) and in a very unusual way.

The smallest nails, because of their size and in comparisons to the biggest ones, work as ribs, that direct thrusts towards specific structural points, that are expressly reinforced. Outside of this room and all around it, there are a number of architectural elements supporting the dome's thrusts. On the north-eastern side, two couples of niches on two levels correspond to two lunettes inside the room (Fig. 14). To the north-west, a pillar lies behind a third one. To the 


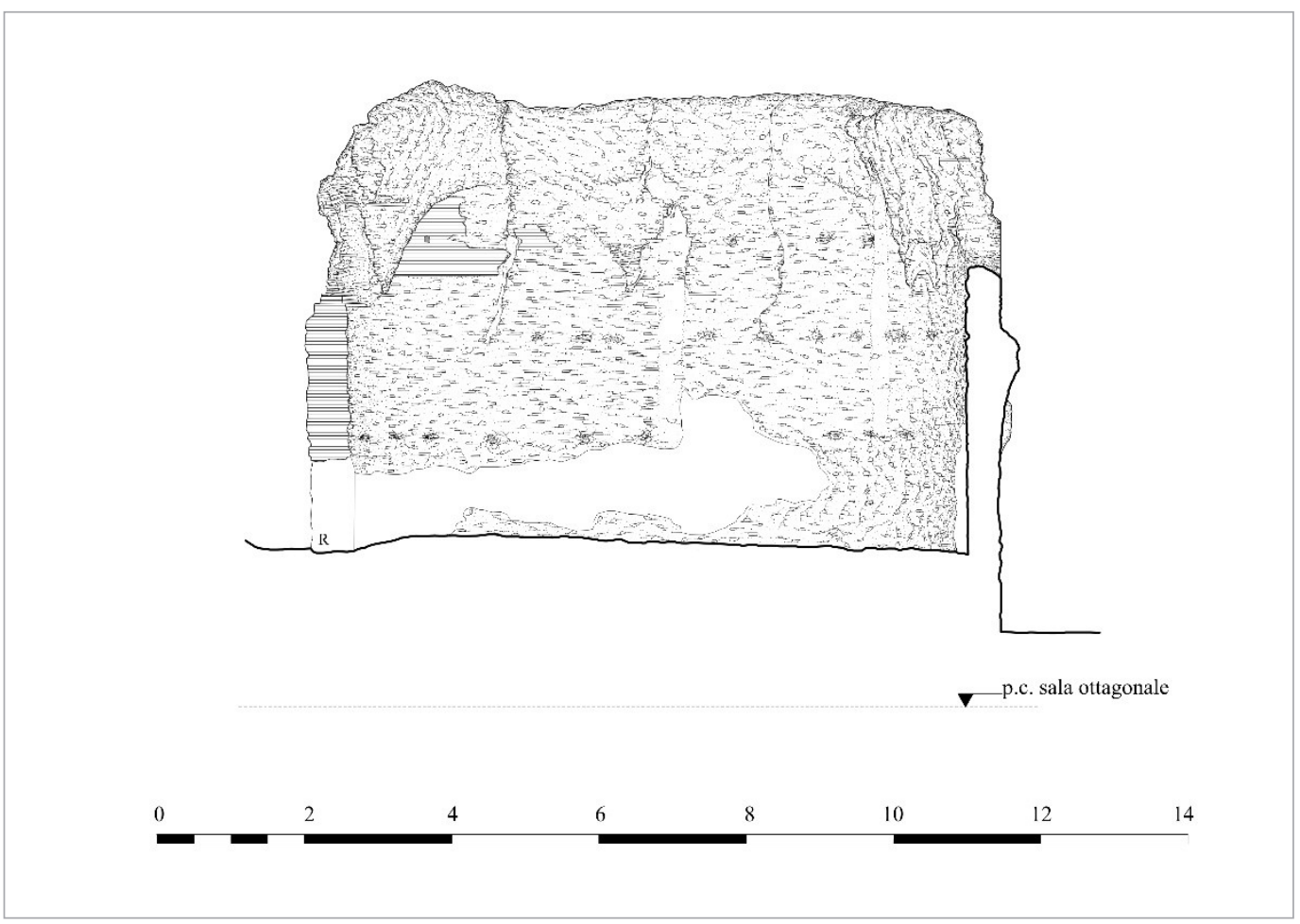

Fig. 13

Architectural survey of north-western section of the round hall (drawing by the author)

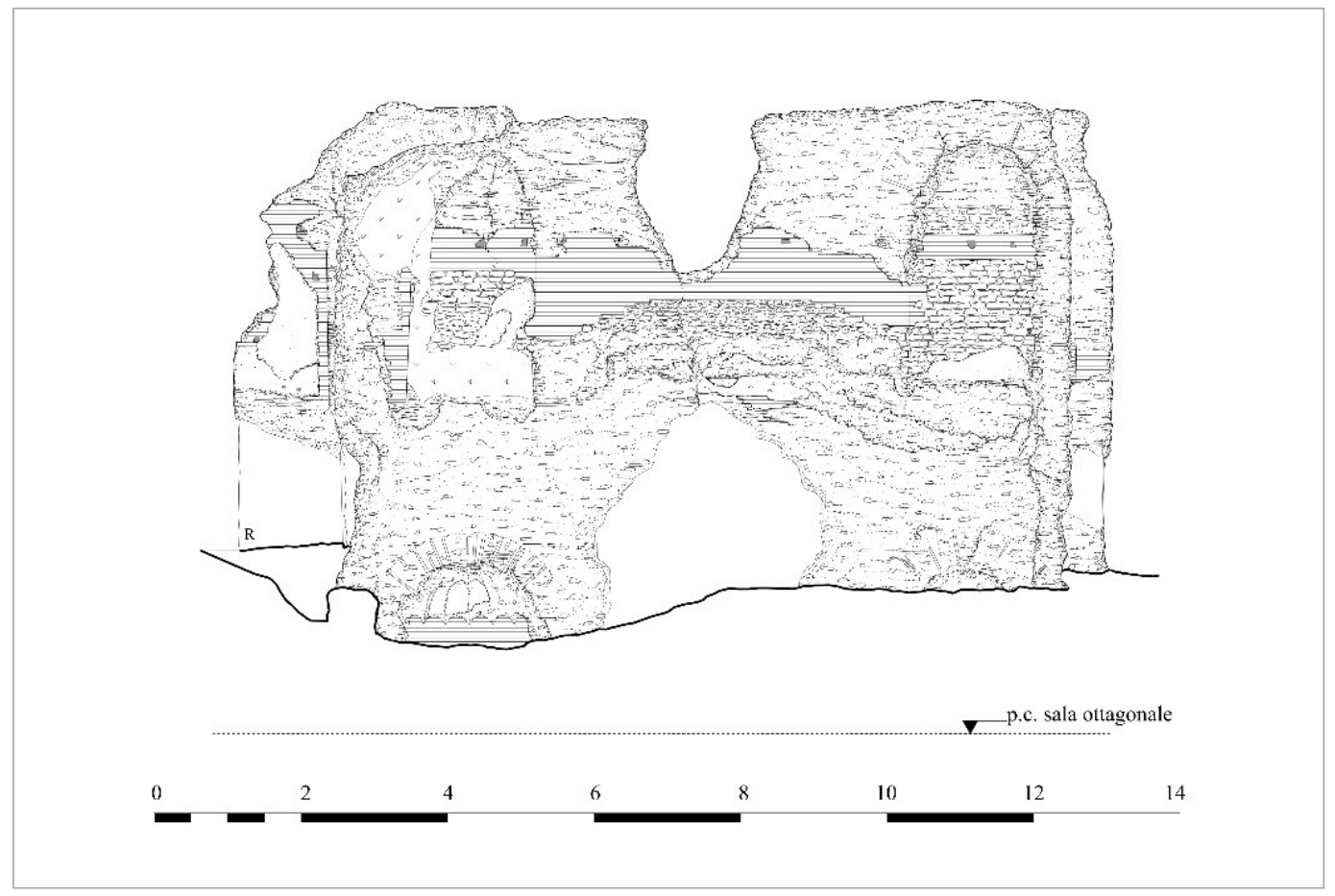

Fig. 14

Architectural survey of exterior north-eastern wall of the round hall: note the niches and the pillar on the right, on the north-western wall (drawing by the author)

south-west, two ribs abutted the springing of the arches of the window, which in turn leaned on two huge masonry edges. Finally, the sixth rib sprang against the south-eastern wall, which was in common with the next room, but masonry is too ruined to allow further speculations. 
Some already-published observations could be revised in the light of the new studies on the monuments.

The main hypothesis concerning the underground channel is that of M. Bertacchini, in collaboration with $\mathrm{L}$. Cenciaioli. They identified the big niches downstream of the theatre as a dam with which Romans blocked the course of the San Vittore stream and thus created an artificial basin. When the sediments deposited by the San Vittore were enough to fill the valley in, Roman engineers would have built a new barrier more upstream, near the thermae: this barrier was identified with the large wall in opus reticulatum found nearby. Roman engineers would then have dug a channel from that point to the theatre, in which they forced the stream to flow. They would have done it just before building the bath complex and maybe exactly for it, when most monuments had already been built and used.

This reconstruction does not seem possible. The hypothesis of Hey, Keay and Millet is even less credible. They report to have seen a section of this channel made in bricks upstream of the baths (Hey-Keay-Millet, 2013, 150), but the only part built in bricks is on the opposite side, downstream of the theatre; the rest of the structure is entirely built in opus reticulatum. Furthermore, they have interpreted the underground structures south of the thermae and near the culvert as a reservoir that, having received water from the culvert, supplied it to the thermae. This structure was identified as a reservoir also by Pannini in the 18th century: this might have led to misunderstandings, but the same scholars have also twisted Pannini's work to support their not-always-acceptable arguments (ibidem, 51-53). Finally, they connect the conduit only with the thermae, but it is linked also to the construction of other buildings.

The holes found at the start of the culvert and the sewer coming from the baths, probably once connected with the main conduit, indicate that this conduit might have been a sewage collector, supplied by a natural stream. This culvert belongs necessarily to the earliest regularisation work undertaken before the construction of the other buildings: the bath complex, the theatre scene and the possible porticus post scenam, the southernmost part of the "Great Substructures", some buried structures in front of them and another isolated structure further southwards were built on the artificial terrace over the underground course of the San Vittore stream.

The exact age of aforementioned building is unknown, except for thermae and for the no-longer visible theatre scene. Based on an inscription ( $\mathrm{ClL} \mathrm{XI}, 7806)$, dated back to the 1st century AD and mentioning a possible dedication(e) scaenae, the scene may have been built in this period. This inscription made it possible to date the construction of the culvert and the filling of the valley before that. Furthermore, even if it is not possible to date buildings based on building techniques, in this case they can be really relevant. If the culvert was strictly connected with the baths, it shall have been built in bricks. On the contrary, the culvert was built in opus reticulatum, like most monuments of the city dated to the 1st century $\mathrm{BC} / 1$ st century $\mathrm{AD}$. It is possible, therefore, to date the channel and the construction of the terrace within this period, when the settlement experienced an intense urbanization.

It is not clear how and when this conduit collapsed and was refurbished. Some elements, however, suggest that after the abandonment of the city and the dismantling of the monuments and before the 18th century, the first section of the vault collapsed, blocking the water-course and forcing the stream to flow outside. It caused the flooding of the lower terrace of the city and its progressive filling with sediments. It clarifies why this side, following the stream course, is nowadays covered by a thick layer of "Loamy sand due to mudflow". What Bertacchini confused with remains of construction is in fact the result of destruction. But under this mudflow, the same scholar noticed the presence of backfill soil (Bertacchini-Cenciaioli, 2003, 213). It proves that culvert was not dug under incoherent and moist sediments, but that it was built while they were filling the valley, up to covering the completed channel. Moreover, the walls in opus reticulatum near the thermae and near the theatre could be revetment walls that had to split the backfill soil for better controlling its adjustment. 
Later on, due to the large amount of water and sediments, the substructures downstream the theatre together with last part of the channel collapsed and, probably shortly thereafter, another large section of channel upstream of the baths collapsed, allowing the stream to flow back inside it. This allowed the stream to create the deep gorge that we see today. It gradually eroded its own sediments and eventually discovered the exterior of the first part of culvert, previously occluded, and flowed on its southern part. Moreover, from the holes on the vault, the stream took away the mud below them, clearing a little part of this thus-far-unused segment. Probably at a later stage the mill at the end of the culvert was built within the ruined area, and the section of the culvert was restored with recycling bricks. The section was narrowed perhaps for the purpose of increasing water pressure, in order to give more energy to the wheel.

As far as the baths are concerned, they perfectly fit in the period to which they belong, from an architectural point of view. The plans and domes of the surviving halls are an excellent example of buildings dated to Hadrian's architectural experimentations. From Baia (Pozzuoli; De Angelis d'Ossat, 1977, 243-252; Crema, 1958, 137-138) to Hadrian's Villa (Tivoli; ibidem, 473-477), the emperor connected circular (and especially octagonal) plans with several kinds of roofing, both in bath complexes and in other kind of buildings. In bath complexes of this period, circular plans featured increasingly in heated rooms. Elsewhere, octagonal halls with several accesses could have been atria (Thermae with Heliocaminus in Hadrian's Villa), heated rooms (ibidem the Small Thermae and the Thermae of the Forum in Ostia) and many other kinds of location.

The round hall of Ocriculum most likely was the last and hottest of the heated rooms (laconicum): this room suggests, the presence of at least two additional rooms on its south-eastern side. The first, immediately adjacent to the round hall, shall have had a rectangular plan (about $\mathrm{m} 7.40$ large and $\mathrm{m} 12$ long) with a curved side opened to the south-west. The second, (about $\mathrm{m}$ 9,40 large and $m$ 14) most likely was above the first, and was probably connected with the octagonal hall on the north-eastern side. It is quite sure that there was another room, because of the passage in the southern niche of the octagon, but it is not certain that it was a heated room and what its measures might have been.

The octagonal room, provided with five accesses on four of its sides, must have been a junction room, an atrium, preceded by a squared vestibule on the south-east. The dome and its joints with the octagonal plan are the most important features of this hall. The so-called "shell-shaped" dome is the only known example in the Roman world. A similar dome is in the so-called "Villa dei Gordiani" in Rome, on the via Praenestina, but it is a semi-circular nymphaeum, roofed by a semi-spherical "shell-shaped" dome. This building, furthermore, dates to the 3rd century. (Maiuro, 2005, 31-39). The baths of Ocriculum, instead, feature a complete, semi-spherical dome dated back to the 2nd century AD. Ribs in domes, not resting on the springing, date back to the 3rd century: the earliest example can be found in "Tor de' Schiavi", another monument of "Villa dei Gordiani". The joints between the dome and the walls are also the earliest seen in the Roman world. Some similar ones were used along via Nomentana in the tomb of Cecchina and in the so-called "Sedia del Diavolo", but these connect a dome with a simple square plan (Crema, 1958, 340.; Carbonara-Messineo, 1996, 29-31). Only in a room of the Baths of Caracalla (Crema, 1958, 340 ) it is possible to see connectors like the one found in Ocriculum, again in the 3rd century AD.

Therefore, what we can see in Ocriculum is very interesting: here there was a dodecagonal plan dome, working as a hexagonal one and another segmental dome composed by 41 elements, working as a regular semi-spherical dome. The skill of hiding some structural behaviour behind architectural shapes that usually behave differently, has reached, in a small and not so known city, levels as high as those in Rome and in other important cities. Moreover, Ocriculum's thermae preceded and possibly even inspire later, more important buildings, and established a connection between Hadrian and the Severan period. 
The attention paid to this monument by the urban community is impressive. Assuming that thermae hiemales was an extension of uncertain dating of the 2 nd-century thermae, it must be noted that the citizens of Ocriculum took care of this building at least until the early 5th century, when the latest known refurbishment was undertaken. At that time, barbarian invasions raged, and soon Rome itself would have been seized by the Goths. If in Ocriculum it was still needed to restore an important but not so essential building as the thermae, it means that the settlement was still active and prosperous, despite the Barbarians and despite the spread of the new religion. It is possible that, starting from this period, the baths were definitively abandoned, probably because of the Christian creed, due to which, in the 7th century, a new baptistery was built not far from the pagan baths.

\section{Conclusions}

To summarise, the importance of the buildings described above is clear: a vaulted channel that uses a natural stream to work as a sewer under the first terrace of the city and a bath complex, built on this terrace, that shows advanced structural solutions and connects two architectural traditions, that of the Hadrianic period and that of the 3rd century. Even if it is not stated anywhere in scholarship, the buildings might most likely have been either promoted or even sponsored by the imperial house. Their position, furthermore, is obviously connected with the culvert, but not in the same way as earlier works assert. The bath complex had a water disposal system that converged in the conduit and, surely, there was a water supply system that probably started from the upper reservoirs (those behind the Nympheum and the two big reservoirs in found "Cisterna" and "San Fulgenzio", the latter interpreted as a castellum acquae for the whole city from the British scholars; Hey-Keay-Millet 2013, 74). Why should the citizens of Ocriculum take water from a stream, when all around the city there were (and there still are) several natural springs, one of which (probably that corresponding to the fountain of "Crocifisso" or to the fountain of "Acqua Salsa") was already picked up from the aqueduct of the cistern in found "San Fulgenzio"?

What has just been described, additionally, as well as providing new data for the understanding of Ocriculum, shows how important and wealthy this city was. Clearly, trade over the river and over the via Flaminia allowed the urban community to considerably increase the city's wealth, and to establish a new settlement near the harbour on the Tiber. It was possible only with massive regularisations, which would have certainly occurred in a bigger city, but was not usual in small towns. Ocriculum, in its wealthiest period, (2nd century AD, when the thermae were built, had more than 4,000 people and extended for approximately 30 ha (Hey-Keay-Millet 2013, 151-152, assumed that Ocriculum had about 2,100 people and extended for 14.2 ha. In that occasion, however, the settlement on the top of the hill and the whole extension of the lower settlement have not been considered. Today, it is possible to assume that the settlement on the top of the hill had been inhabited during the imperial period, and that there has not been any break in continuity between the two centres. In fact, tombs, that usually help to identify the borders of Roman towns, have been found along the via Flaminia only to south of the lower city, Cenciaioli 2002, 282-285, and north of the upper, Pietrangeli 1978, 170. Moreover in 1981 a Roman reservoir, not better dated, was accidently found in the town hall square of the modern city, Cenciaioli 2008, 812-813). It proves that this town was inhabited by an élite composed mainly by wealthy merchants. This is further underlined by the huge quantity of fine art objects found during 18th century and modern excavations.

The still-standing buildings testify to the wealth of the élite of Ocriculum. The underground channel, however, shows that still-unknown evidence might offer a key for a more thorough understanding of the city. The impressive regularisation, which exploited even a natural watercourse, was made possible with a large use of men and resources, and demonstrates that Ocriculum was not a simple harbour on the Tiber. A culvert buried under a terrace on which the two most lavish buildings of the city, the thermae and the theatre scene, were built in different periods, can be compared with the Cloaca Maxima in Rome, that also exploits a natural stream to allow water to flow (it is essential in a sewer that the water flows continuously, not to create unhealthy stagnations). The importance of those structures explains clearly the level of this conduit. This 
and the innovative structures of the bath complex (clearly sponsored by an emperor) suggest that Ocriculum should be more considered by modern archaeologists.

The results presented above are far from being definitive. Much more could be said about Ocriculum, but substantial evidence is still to be brought to light. A considerable wealth of information, furthermore, can be found in archives. The British School surveys shall be taken cautiously in regard to interpretations, but is very important for data collections. The data they have gathered can be helpful for new investigations. The culvert shall be accurately inspected and emptied from the sediments, in order to survey its whole course and to allow visitors to access it. The studies led by the Superintendence in the 1960s and 1970s have not been completely published: most of them are still unknown and confined within public private archives of Umbria, Toscana, Marche and Lazio. A thorough knowledge of Ocriculum shall necessary build upon the aforementioned sources, which must merge with data from new research.

Leonardo Radicioni and other colleagues for their cooperation during the surveys.

Alice Poletto and Luca Volpi for editorial assistance.

Prof. Alessandra Ten for supervising and directing my work.

Prof. Luisa Migliorati for her help and suggestions.

Dr. Luana Cenciaoli for her willingness to cooperate.

Otricoli City Council and "Ocriculum AD 168" cultural association for their passion and cooperation with during my work.

Bertacchini M., Geologia tra passato e presente nel territorio di Ocriculum [Geology between the past and the present on the Ocriculum territory]. Un museo per Otricoli. Perugia: Fabrizio Fabbri Editore; 2006: 11-18.

Bertacchini M., Cenciaioli L., Uno sguardo sulla città romana di Ocriculum [A look at the Roman town of Ocriculum]. II Quaternario, Italian Journal of Quaternary Sciences, 2003; 16(2): 207-213.

Bertacchini M., Cenciaioli L., The past and the presentof the roman town of Ocriculum (Umbria). Mercator placidissimus. The Tiber valley in antiquity. Rome: Edizioni Quasar; 2008: 837-847.

Caldelli M.L., Nuovo peso iscritto da Otricoli [New inscribed pound from Otricoli]. Epigraphica, 1995; LVI-1994, 200-210.

Carbonara A. - Messineo G., Via Nomentana. Rome: Ist. Poligrafico dello Stato; 1996.

Cenciaioli L., Ocriculum. Guida ai monumenti della città antica [Guide-book for the ancient tonw monuments]. Perugia: Soprintendenza Archeologica per l'Umbria; 2000.

Cenciaioli L., Il territorio di Otricoli fra Umbri e Sabini [Otricoli's territory between Umbrian and Sabine]. Annali della fondazione per il museo "Claudio Faina", 2001; VIII, 293-318.

Cenciaioli L., Un museo per Otricoli [A museum for Otricoli]. Perugia: Fabrizio Fabbri Editore; 2006.
Cenciaioli L., Otricoli: nuove ricerche e recenti acquisizioni della Soprintendenza per i Beni Archeologici dell'Umbria [Otricoli: new researches and last acquisition lead by Superintendence for Cultural Heritage of Umbria]. Mercator placidissimus. The Tiber valley in antiquity. Rome: Edizioni Quasar; 2008: 811-831.

Cenciaioli L., Otricoli (TR). Terme di Iulius Iulianus. Nuovi dati per la ricostruzione del mosaico pavimentale della sala ottagonale [Otricoli (TR). Iulius Iulianus baths. New data for the reconstruction of the pavement mosaic from the octagonal hall]. Atti del XVII Colloquio dell'Associazione Italiana per lo Studio e la Conservazione del Masaico, 2012: 169-177.

Crema L., L'Architettura romana [Roman Architecture], Torino: Società Editrice Internazionale; 1959.

De Angelis d'Ossat G., Sugli edifici ottagonali a cupola nell'antichità e nel medioevo [Regarding domed octagonal buildings in antiquity and in the middle-age]. Realtà dell'architettura: apporti alla sua storia, 1933-78, 1982: 159-171, Tavv. XXXIX-XL.

De Angelis D'Ossat G., L'architettura delle terme di Baia [Baia baths architecture]. Atti del Convegno: I Campi Flegrei nell'Archeologia e nella Storia, 1977; 33: 227-274.

De Rubertis R., Rilievi archeologici in Umbria [Archaeological survey in Umbria]. Napoli: Edizioni Scientifiche e Artistiche; 2011.

Filippi G., Ocriculana. Scritti di archeologia e storia

\section{Acknow- ledgment}

\section{References}


dell'arte in onore di Carlo Pietrangeli, 1996: 73-100. Giuliani C.F., Il Lato Nord ovest della Piazza d'Oro [The north-west side of the Gold Square]. Ricerche sull'architettura di Villa Adriana, 1975: 3-53.

Giuliani C.F., La Villa [The house]. AA. VV., Villa Adriana. Rome, 1988: 71-145.

Giuliani C. F., L'edilizia nell'antichità [Building in antiquity]. Rome: Carocci Editore; 2006.

Giuliani C. F., Il quadro fessurativo nello studio dei monumenti antichi [The cracking pattern in the ancient monuments study]. Tivoli: Tiburis Artistica; 2016.

Gros P., Torelli M., Storia dell'urbanistica. Il mondo romano [Urban planning history. Roman world]. Roma-Bari: Laterza; 1988.

Guattani G. A., Monumenti antichi inediti per l'anno MDCCLXXXIV [Unpublished ancient monuments for year 1784]. Rome, 1784.

Guattani G. A., Monumenti antichi inediti per l'anno MDCCLXXXV [Unpublished ancient monuments for year 1785]. Rome, 1784.

Hay S., Keay S., Millet M., Ocriculum (Otricoli, Umbria). An archaeological survey of the roman town. London: British Academy; 2013.

Lancaster L. C., Concrete vaulted costruction in imperial. Rome, Cambridge: Cambridge University Press; 2005. https://doi.org/10.1017/CB09780511610516

Maiuro M., Gordianorum Villa. LTURS III G-L, Roma, 2005: 31-39.

Nielsen I., Thermae et Balnea, the architectural and cultural history of Roman Public Baths. Viborg: Aarhus Universitetsforlag; 1990.

Pani Ermini L., "Forma" e cultura della città altomedievale [Shape and culture of early-medieval town]. Spoleto: Fondazione CISAM; 2001.

Pavolini C. Ostia. Roma-Bari: Laterza; 2006.

Pietrangeli C., Note di epigrafia otricolana [Notes of otricolan epigraphy]. Epigraphica, 1941; III: 135-159 and 302-304.

Pietrangeli C., Lo scavo pontificio di Otricoli [Papal excavation in Otricoli]. Rendiconti della Pontificia Ac- cademia Romana di Archeologia, 1944; XIX: 47-104. Pietrangeli C., Ocriculum (Otricoli). Rome, Ist. Nazionale di Studi Romani; 1943.

Pietrangeli C., Scavi e scoperte di antichità sotto il pontificato di Pio VI [Excavations and ancient items discovering under the pontificate of Pious VI ]. Rome: Istituto di Studi Romani Editore; 1958.

Pietrangeli C., Otricoli. Un lembo dell'Umbria alle porte di Roma [Otricoli. An Umbria's part at Roma's gates]. Rome: Ugo Bozzi Editore; 1978.

Rossi Caponeri M., David E., Il Tevere a Otricoli. Vita e fede sulle rive del fiume [Tiber in Otricoli. Life and faith on the river banks ]. Viterbo: Betagamma Editrice; 2012.

Sommella P., Italia antica. L'urbanistica romana [Ancient Italy. Roman urban planning]. Rome: Jouvence Società Editoriale; 1988.

Uggeri A., Journées pittoresques des edifices de Rome ancienne par l'abbe architecte Ange Uggeri [Picturesques days of ancient Rome buildings by the architect abbot Angiolo Uggeri], Vol. III. Rome: Aedibus capitolini; 1802

Verduchi P., Le terme con cosidetto heliocaminus [Baths with s.c. heliocaminus]. Ricerche sull'architettura di Villa Adriana, Rome, 1975, 55-95.

\section{Ancient authors and inscriptions}

Corpus Inscriptionum Latinarum, vol. VI, 872=31188.

Corpus Inscriptionum Latinarum, vol. XI, 4090, 4094-4097, 7086.

Corpus Inscriptionum Latinarum, vol. XV, 1078.

G. Plinius Cecilius Secundus, Epistoles, I, 4, 1. Inscriptiones Christianae Italiae, vol. VI, 3.

M. Tullius Cicero, Pro Milone, 24, 64.

P. Annius Florus, Epitome de Tito Livio, II, 6, 11.

T. Livius, Ab Urbe condita, vol. IX, 41, 20.

\section{Archive's abbreviations}

ASR = Archivio di Stato di Roma [National Archive of Rome].

MAEC $=$ Museo dell'Accademia Etrusca della città di Cortona [Etruscan Academy Museum of Cortona].

\section{About the Author \\ GIACOMO ANTONELLI}

Phd student

Archaeology at "Sapienza" University of Rome, Faculty of Humanities, Department of Classics

\section{Main research area}

Ancient Topography

\section{Address}

"Sapienza" University of Rome, Faculty of Arts and Humanities, Department of Classics,

Piazzale Aldo Moro 5, 00185 Rome, Italy

E-mail: giacomo.antonelli@uniroma1.it 